\title{
RELIGIÓN, ESTADO Y NACIÓN EN ESPAÑA Y MÉXICO EN EL SIGLO XIX: UNA PERSPECTIVA COMPARADA
}

\author{
Manuel Suárez Cortina \\ Universidad de Cantabria*
}

\section{INTRODUCCIÓN}

7 ste artículo ${ }^{1}$ aborda las relaciones entre religión, EstaEdo y nación en España y México en el siglo xIx. En el mismo se pone de manifiesto la persistencia de elementos comunes en las sociedades mexicana y española, con una fuerte presencia del catolicismo, pero con no menos diferencias sustanciales, con dos liberalismos que abordaron de forma distinta la inserción de la Iglesia en el nuevo orden político. Tras la crisis de la Monarquía Católica, la omnipresencia

Fecha de recepción: 15 de febrero de 2016

Fecha de aceptación: 19 de mayo de 2016

* Grupo de investigación Historia y Cultura Contemporánea de Europa del Sur y América Latina (HCESAL).

${ }^{1}$ Este ensayo se inserta en el proyecto de investigación "Estado, nación y nacionalización en la Europa del sur y América Latina en la época liberal (1850-1930). Una perspectiva comparada" (Ref. HAR2015-64419-P). Ministerio de Economía y Competitividad del Gobierno de España. IP: Manuel Suárez Cortina. 
de la Iglesia estuvo en la base de la intolerancia religiosa que dominó ambos estados en sus primeras décadas. El mejor ejemplo lo representa el tratamiento constitucional de la cuestión religiosa que dieron los textos español de 1812 y mexicano de 1824. Las reformas liberales y la reacomodación de la Iglesia al nuevo orden liberal se llevaron a cabo, sin embargo, de una forma distinta, sobre todo a partir de la segunda mitad del siglo xIx, cuando las Leyes de Reforma en México impusieron la separación de la Iglesia y el Estado, en abierto contraste con España que, desde 1851, con el Concordato con el Vaticano, estableció la confesionalidad del Estado y facilitó a la Iglesia un amplio margen de maniobra en el orden moral y educativo.

Antes y después del medio siglo no se puso en cuestión el carácter mayoritario del catolicismo como religión de españoles y mexicanos, sin embargo, el tratamiento que los liberales dieron a la cuestión religiosa en los dos países se fue distanciando a partir de 1850 . Hay que resaltar que los liberales mexicanos apostaron por un proceso secularizador del Estado, en abierto contraste con el liberalismo español, que, en su corriente dominante, la conservadora, pugnaba por la defensa de la confesionalidad. Para adentrarnos en España en una posición separatista hemos de ir al terreno del republicanismo, cuyo liberalismo radical apostaba por la secularización del Estado, cuando no de la sociedad toda. El liberalismo posrevolucionario, por su parte, se escindía entre su variante progresista, que defendía la tolerancia religiosa, y un moderantismo que tuvo por enseña la unidad católica y un declarado rechazo a toda tolerancia religiosa.

La comparación de las experiencias mexicana y española ilustra muy bien dos propuestas de reacomodación de la 
Iglesia y el catolicismo en dos sociedades donde no se ponía en duda la catolicidad de los ciudadanos, sino el papel que le correspondió a la Iglesia en el nuevo orden político, y el distinto sentido que liberales y conservadores asignaron a la religión en la conformación de la identidad nacional.

\section{CUESTIÓN RELIGIOSA, NACIÓN Y MODERNIDAD}

La cuestión religiosa y la inserción de las Iglesias en las sociedades modernas están marcadas por complejidades que dificultan una caracterización simple. Es conocida una vieja tradición de la sociología e historiografía de la religión que ha planteado una dicotomía entre sociedades tradicionales y modernas a partir de la afirmación de los componentes religiosos de aquélla y la creciente secularización de la sociedad contemporánea. Es sabido, no obstante, que en las últimas décadas se ha suavizado este carácter secularizador de la modernidad, pero no cabe duda que de forma heurística la dualidad de una sociedad tradicional dominada por la religión y una contemporánea determinada por sus componentes secularizadores sigue constituyendo una referencia apreciable para explicar el alcance de la religión y las iglesias en ambas sociedades.

Este modelo de confrontación entre tradición y modernidad puede servirnos, aunque con cautela, para el estudio de las relaciones entre religión, Estado y nación en España y México en el siglo xix. Surgidos ambos países de la descomposición de la Monarquía Católica o Hispánica, resulta indudable que sus habitantes nacieron y crecieron en el marco de una cultura profundamente católica. Fueron, es innegable, naciones católicas, y los marcos institucionales 
desarrollados tras la independencia en México y la revolución liberal en España estuvieron fuertemente impregnados de catolicismo y de la omnipresencia de la Iglesia católica. En este sentido la relación entre religión, Estado y nación se presenta cargada de registros y no menos de tensiones, una vez que los nuevos regímenes representativos - la monarquía constitucional en España y la república federal en México - apostaron por el fortalecimiento de su jurisdicción, pero no dudaron del componente católico de la nación, cuando no también del Estado. Más aún, en el caso mexicano, durante décadas la Iglesia como corporación mantuvo el fuero, hasta su eliminación por la Ley Juárez en $1855 .^{2}$

Aun siendo conscientes de la dificultad de atender todos los registros y variantes que ofrece esa plural relación entre la Iglesia, la articulación del nuevo orden político y la sensibilidad religiosa de españoles y mexicanos, vamos a prestar atención a tres componentes: el primero hace referencia a la relación que se produce entre religión, modernidad y nación; el segundo se ocupa del tratamiento que el Estado dio a la cuestión religiosa, tanto en sus constituciones como en la política eclesiástica desarrollada por los diversos gobiernos españoles y mexicanos. Finalmente, en el tercero, haremos una breve incursión en la relación entre nación y religión y los distintos discursos elaborados por conservadores y liberales en los dos países. En el mismo se dejan al descubierto las similitudes y diferencias que se produjeron entre las concepciones de los dos liberalismos mexicano y español, y no menos, las afinidades que un liberalismo radical

${ }^{2}$ López GonZÁlez, “La Ley Juárez”, pp. 191-214. 
mostró a ambos lados del Atlántico en el desarrollo de prácticas anticlericales, cuando no declaradamente antirreligiosas y hasta sacrofóbicas. ${ }^{3}$

Las páginas que siguen son necesariamente esquemáticas, toda vez que el tratamiento de los temas aquí apuntados reclama una atención mucho más amplia, que no es posible cubrir en todas sus dimensiones en el marco de este artículo. En todo caso, no se trata de agotar el tema, sino de ilustrar las semejanzas y diferencias que caracterizaron las relaciones Iglesia-Estado y las distintas políticas religiosas que dos países nacidos de la Monarquía Católica desarrollaron tras su conversión en Estados-nación. Siempre según la idea de que el Estado y la nación, aunque unidos en el marco político jurídico del Estado-nación, tuvieron, sin embargo, tempos y ritmos diferentes. En el caso mexicano fue previo el Estado a la construcción de una nación que sólo fue tomando forma definitiva avanzado el siglo XIx. ${ }^{4}$ En el caso español, aunque tuvo como precedente una monarquía que desde el siglo XviII desarrolló cierta cultura nacional, no es menos cierto que fue también tras la construcción del Estado liberal cuando se articularon los instrumentos institucionales y

${ }_{3}$ Para un acercamiento al anticlericalismo en España y México véanse LA Parra y SuÁrez Cortina (eds.), El anticlericalismo español contemporáneo; Cruz (ed.), El anticlericalismo; SAVArino y Mutolo (coords.), El anticlericalismo en México; Solis y SAVARINo (coords.), El anticlericalismo en Europa y América latina.

${ }^{4}$ Sobre el origen de México como Estado-nación independiente y el papel que en ese proceso tuvo el nacionalismo véase Pérez Vejo, "El problema de la nación en las independencias"; para el desarrollo de ambos países en la primera mitad del siglo xix, RodríGuez O. (coord.), Las nuevas naciones. 
culturales configuradores de la nación española. ${ }^{5}$ Los procesos, pues, de construcción del Estado, de la nación y la nacionalización de los españoles tuvieron también sus particulares tempos.

Con todo, hay que reseñar que este análisis de la religión y la modernidad ha sido abordado preferentemente desde el marco institucional y no siempre se ha prestado atención a otras dimensiones de la vida religiosa, tales como el campo de la cultura popular y los modos diversos y sincréticos que a menudo han caracterizado el universo cultural de las clases populares. Este ámbito, de especial relevancia en el México del siglo xIx, ha sido mayoritariamente soslayado por aquellos estudios que hacen hincapié en el Estado laico, ya desde la sociología o la historia, dejando a un lado ese enorme campo de la cultura popular y su religiosidad del que se ha ocupado la antropología social. ${ }^{6}$ Es oportuno señalar igualmente que aquí no nos ocupamos de la relación entre religión y nación en las experiencias de los nacionalismos vasco y catalán, sino explícitamente del nacionalismo español, el dominante casi en exclusividad en el siglo XIX.

La historiografía reciente nos ha advertido de la conveniencia de no tomar de forma dogmática la clásica concepción dicotómica de una sociedad tradicional religiosa frente

\footnotetext{
${ }^{5}$ Sobre el nacionalismo y los procesos de nacionalización en España véanse Morales Moya, Fusi y Blas (eds.), Historia de la nación; Moreno Luzón y Archiles (eds.), Construir España; Archilés, García CARrIón y SAz (eds.), Nación y nacionalización.

${ }^{6}$ Véase, en este sentido, el trabajo de Iparraguirre, "Liberalismo, catolicismo y religiosidad popular”, pp. 141-164; para el caso español véase Álvarez Santalló, Buxó i Rey, Rodríguez Becerra (coords.), La religiosidad popular.
} 
a una modernidad secularizada. ${ }^{7}$ Con todo, resulta imposible no tomar como punto de partida una vieja dicotomía que la antropología, la ciencia política, la historia o la sociología de la religión han desarrollado como un instrumento analítico necesario para una ajustada caracterización del papel de la religión y de las instituciones religiosas antes y después del nacimiento y desarrollo del Estado-nación. Más allá de que sigamos los postulados de la dualidad entre tradición/modernidad y su correspondiente religiosidad/secularización, resulta indudable que el desarrollo de una cultura moderna y el triunfo del Estado-nación, con sus regímenes representativos, expresaron una reformulación del lugar de la religión en la vida social y no menos un replanteamiento del papel social, económico e institucional de las iglesias en el nuevo orden político jurídico. Si interpretamos la secularización de una forma más o menos dogmática, es incuestionable que la modernidad - con su innegable carga de pluralidad semántica - representó el fortalecimiento de la secularización y con ello la transformación de lo religioso en varias modalidades: fortalecimiento de la dimensión individual de la religión, desencantamiento del mundo y separación de las esferas eclesiástica y estatal. ${ }^{8}$ Este proceso se desarrolló en cada lugar según tradiciones particulares, pero

7 En el caso mexicano véase Connaugthon, Entre la voz de Dios; para España véase Louzao, Soldados de la fe o amantes del progreso; "La recomposición religiosa en la modernidad”, pp. 331-354. Una mirada conjunta sobre los casos español y mexicano en SuÁrez Cortina, Trejo Estrada y Cano (eds.), Cuestión religiosa.

8 Véase, en este sentido, Dobbelaere, "Secularization"; Casanova, Public Religions in the Modern World. Una revisión del tratamiento de la secularización por la sociología de la religión puede encontrarse en DAviE, Sociología de la religión. Un análisis reciente del tema en LouzAO, 
en el caso de los países latinos el proceso tuvo que superar fuertes tensiones que, con frecuencia, llegaron al conflicto civil. ${ }^{9}$ Conviene resaltar que este proceso secularizador no conlleva obligadamente la desaparición o debilitamiento de la religión en las sociedades, sino una transformación profunda que en cada caso se ha gestionado de formas muy dispares. Un país como Estados Unidos tuvo desde el principio una separación de poderes que no afectó a la fuerza de las diversas religiones en la sociedad estadounidense. Por el contrario, en los países latinos, ese proceso conoció fuertes controversias que marcaron una diversidad de situaciones. En España provocó una confrontación abierta entre confesionalidad y secularización, en contraste con Polonia, donde la Iglesia se fortaleció y la oposición a la secularización se asoció con la resistencia al Estado comunista ganando en legitimidad social y manteniendo unas altas tasas de práctica religiosa. ${ }^{10}$

La historiografía reciente sobre la nación y el nacionalismo ha prestado mucha atención a las relaciones entre nación y religión. A. D. Smith, desde una perspectiva "modernista" ha resaltado cómo el nacionalismo es visto como una ideología moderna, secular, que ha reemplazado los sistemas religiosos dominantes en las sociedades tradicionales. ${ }^{11}$ Bajo

\footnotetext{
"La recomposición religiosa en la modernidad”, pp. 331-354. Véase el monográfico coordinado por Louzao, "Modernidad y catolicismo".

9 Una aproximación a los problemas que plantea la modernidad religiosa en los países latinos puede verse en BASTIAN (coord.), La modernidad religiosa.

10 Para el análisis de varios casos europeos véase Haupt y LANDGEwiesCHE (eds.), Nación y religión en Europa.

11 Sмiтh, Nacionalismo.
} 
este prisma "modernista”, religión y nacionalismo se nos aparecen como dos referentes antagónicos que expresan las variantes de tradición y modernidad. Por su parte, A. Hastings, en sentido opuesto, ha resaltado el papel de la religión en la configuración de las naciones. ${ }^{12}$ Esta confrontación entre modernistas y tradicionales ha perdido en los últimos años sus rasgos más radicales. El mismo Smith ha reconocido los componentes tradicionales y populares que están en la base de toda nación y ha resaltado que son mucho más que una cultura secular, conformándose, de hecho, como una "religión política", utilizando una concepción funcionalista que ha tomado de Émile Durkheim. La manifestación de esta religión política se observa en el gusto que los nacionalismos tienen por las ceremonias conmemorativas de los grandes líderes nacionales o los muertos por la patria. ${ }^{13}$

Las relaciones entre nacionalismo y religión se nos presentan, pues, cargadas de complejidad. En unos casos el triunfo del nacionalismo y de su expresión político jurídica, el Estado nación, ha significado una fuerte acción secularizadora, cuando no puramente laicista, como en el caso de Francia; en otros, por el contrario, fue perfectamente compatible el nuevo Estado con formas confesionales o no, pero a menudo con una amplia aceptación del fenómeno religioso en la sociedad. A pesar del proceso secularizador claramente perceptible, las religiones se han adaptado, han perdido sus caracteres previos y se han mutado para sobrevivir en un mundo nuevo, en el que ni la religión ni la Iglesia son ya el centro neurálgico del orden social. Se han "modernizado",

12 Hastings, La construcción de las nacionalidades.

13 Véase, en este sentido, Mess (ed.), La celebración de la nación. 
eliminando su aspiración de ocupar todo el espacio social, sus aristas dogmáticas y, finalmente, y con múltiples frenos, se han abierto a un diálogo con otras creencias, religiosas o no. De todos modos, como resalta Sabina Mihelj, tanto los teóricos modernistas del nacionalismo, como sus críticos, tienden a eludir las versiones más fuertes de la secularización y establecen una aguda distinción entre el nacionalismo secular (incluso antirreligioso) por una parte, y el nacionalismo religioso (antisecular) por otra. Para Mihelj estas dos propuestas pueden entenderse como expresión de dos opuestos entre los cuales cabe encontrar territorios intermedios de nacionalismos, señalados por ideas y símbolos religiosos que no son opuestos necesariamente a la visión modernista, secular, del mundo. ${ }^{14}$

La realidad muestra que la relación entre religión y nacionalismo es, en sí misma, compleja y multidimensional, y que las distintas ciencias sociales y humanas han abordado esa relación de formas muy diversas. Rogers Brubaker ha considerado la relación entre nacionalismo y religión desde cuatro posiciones: ya como fenómenos análogos, ya considerando la religión como origen o explicación del nacionalismo, ya como dos fenómenos distintos, pero imbricados, o bien, finalmente, considerando el nacionalismo religioso un tipo de nacionalismo. ${ }^{15}$

Las experiencias mexicana y española muestran la fuerte imbricación entre religión y nación, pero no menos, como expresa el caso mexicano de la segunda mitad del siglo XIX, una menor cercanía entre el Estado y la Iglesia, como veremos

\footnotetext{
14 Mihelj, "Faith in nation comes a different guise", pp. 265-284.

15 Brubaker, "Religion and nationalism”, pp. 2-20.
} 
en las páginas siguientes. De otro lado, en el campo político liberales y conservadores mostraron una posición diferenciada en cómo interpretar esa relación entre la religión (en este caso, fundamentalmente la católica) y la nación.

En su desarrollo como naciones independientes México y España mostraron una fuerte presencia de elementos religiosos en su gestación. El catolicismo no fue puesto en cuestión en ningún momento, ni antes ni después de la implosión de la Monarquía Católica. Más aún, los primeros pasos del México insurreccional estuvieron impulsados desde una religiosidad muy intensa, como muestran las insignias de la Virgen de Guadalupe entre los seguidores de Miguel Hidalgo, o Los sentimientos de la nación (1813) de José María Morelos, ${ }^{16}$ y no menos el fuerte componente religioso que se observó en la oposición a Napoleón en la España de $1808 .{ }^{17}$ Esa fuerza de la religión como un elemento constitutivo básico de las nuevas naciones se dejó sentir con claridad en la primera mitad del siglo xIx. En el caso de España se prolongó a lo largo de todo el siglo y hasta muy avanzado el xx, pero en México, como se puso de manifiesto a partir de las Leyes de Reforma, ${ }^{18}$ el liberalismo se alejó de toda propuesta confesional, separó el Estado de la Iglesia y mostró el alcance que tuvo en la segunda mitad del siglo el triunfo de un liberalismo secularizador, en el marco de una sociedad mayoritariamente católica. ${ }^{19}$

${ }_{16}$ Para un análisis de la posición del episcopado ante la independencia véase Pérez Memen, El episcopado y la Independencia de México. 17 Véase Martínez Ruiz y Gil, La Iglesia española contra Napoleón.

18 Véase el conjunto de trabajos recogidos en BlanCARTE (coord.), Las Leyes de Reforma y el Estado laico.

19 Véase, en este sentido, Cannelli, Nación católica y Estado laico. 
En todo caso, como se verá en las páginas siguientes, las relaciones entre la Iglesia y el Estado y la religión y la nación merecen tratamiento independiente, en la medida en que el primero afecta a las relaciones institucionales entre dos entidades "soberanas", en tanto que la segunda remite al papel de la religión, en este caso del catolicismo, en los diversos discursos identitarios que liberales, conservadores y republicanos desarrollaron a lo largo del siglo xIx.

\section{LA IGLESIA Y EL ESTADO LIBERAL EN ESPAÑA Y MÉXICO EN TIEMPOS DE INDEPENDENCIA Y REVOLUCIÓN}

Las relaciones entre el Estado liberal y la Iglesia en España y México vinieron marcadas por un doble elemento. De un lado, por la inequívoca realidad de que las sociedades española y mexicana eran profundamente católicas. Desde la Monarquía Hispánica, tal y como ya había remarcado Feijoo en su Teatro crítico, España era profundamente católica. 150 años más tarde, Jaime Torrubiano Ripoll resaltaba cómo la literatura, las leyes, la vida social y la psicología colectiva estaban impregnadas de un profundo sentido de catolicidad..$^{20}$ El catolicismo, pues, era vivido como una experiencia corriente en los dos países. Los actos de la vida cotidiana estaban presididos por la presencia de la Iglesia y el calendario; las festividades y todas las manifestaciones públicas tuvieron siempre un fuerte contenido religioso. Tanto la independencia de México como la revolución doceañista conocieron la presencia y el dinamismo de un conjunto de eclesiásticos que lideraron junto con los civiles el proceso

20 Torrubiano Ripoll, Politica religiosa de la democracia española. 
de cambio político que siguió a la liquidación de la Monarquía tradicional. No cabe decir que independencia y revolución se llevaran a cabo de espaldas al sentimiento católico de la nación. Ahora bien, el estatuto de la Iglesia habría de experimentar cambios considerables, sobre todo en dos dimensiones. La primera, en su componente económico; la segunda, en la necesaria reforma de sus instituciones, en especial en el papel de las órdenes religiosas, las más afectadas por el carácter reformista del liberalismo. Más adelante se verán las líneas maestras de las reformas liberales respecto de la Iglesia, sus estructuras y organización económica. De momento, cabe resaltar que el nacimiento de los regímenes liberales y las constituciones desarrolladas por México y España estuvieron lejos de lesionar la posición de la religión católica.

El común denominador de las constituciones que mexicanos y españoles elaboraron en la primera mitad del siglo xIX fue precisamente garantizar la catolicidad del Estado y la sociedad. Llama la atención que, formulándose como liberales ambas experiencias, sin embargo, proclamaron en sus constituciones no sólo el carácter católico del Estado, sino la intolerancia religiosa. Tanto el liberalismo hispánico, primero (aquel que sigue la cultura doceañista), como el que se desarrolla en México tras la independencia, se manifiesta como intolerante. Es cierto que en ambos países se oyeron tímidas voces a favor de la tolerancia religiosa, pero sus constituciones establecieron que la religión católica, apostólica y romana era la religión oficial de los nuevos estados. Tanto en la Constitución de Bayona (1808), como en la de 1812, de tanta repercusión en México, se estableció la catolicidad del Estado. En la de 1812 su artículo 12 señalaba: 
"La religión de la nación española es y será perpetuamente la católica, apostólica, romana, única verdadera. La nación la protege por leyes sabias y justas y prohíbe el ejercicio de cualquiera otra”. Esa formulación pasó casi por completo a la Constitución federal de 1824, en la que únicamente se eliminó el término “única verdadera”. Se desarrolló, pues, en la España de la revolución liberal, la ciudadanía católica, aquella fórmula de catolicismo e intolerancia que además se filtraba al ámbito político toda vez que se convertía la parroquia en el punto de partida de un sufragio indirecto para la elección de diputados a Cortes. Era la condición de católico la que permitía a su vez la ciudadanía política. Esa intolerancia fue común a la registrada por la Constitución de Bayona y la de Apatzingán (22 de octubre de 1814). La de Bayona dedicaba un título primero, artículo único, a la religión: “ $\mathrm{La}$ Religión Católica, Apostólica y Romana, en España y en todas las posesiones españolas, será la Religión del Rey y de la Nación, y no se permitirá ninguna otra”. La de Apatzingán señalaba en su artículo primero: "La religión católica, apostólica romana es la única que se debe profesar en el Estado”. La historiografía reciente (Brian Connaugthon, Ana Carolina Ibarra, David Brading, William Taylor, Carlos Herrerón...) ha resaltado el doble carácter democrático y popular, pero también intransigente y jerárquico de José María Morelos, bajo la enseña de "Siervo de la nación”. ${ }^{21}$

En la Monarquía Católica y en el primer liberalismo mexicano y español la intolerancia religiosa constituyó un

21 Para un balance de la Iglesia en tiempos de la independencia véanse, IBARRA, "La historiografía sobre la iglesia y el clero"; Connaugthon, "La nueva historia política y la religiosidad". 
signo de identidad colectiva, frente al cual sólo se pronunciaron algunas voces. En México, José Joaquín Fernández de Lizardi, Andrés Quintana Roo, Juan de Dios Cañedo, Lorenzo Zavala y Vicente Rocafuerte mostraron en distinto grado su desacuerdo con esa intolerancia, pero la mayoría del espectro político no vio contradicción entre sus planteamientos políticos y la intransigencia religiosa. ${ }^{22}$ En España, igualmente fueron escasas las voces que se opusieron a la intolerancia proclamada por el artículo 12 de la Constitución gaditana. Desde el exterior, José María Blanco White y algunos diputados como Álvaro Flórez Estrada, Manuel García Herreros o José María Calatrava, mostraron la conveniencía de permitir una tolerancia religiosa que venía demandada por los tiempos. Álvaro Flórez Estrada, en su defensa de la libertad de imprenta, hacía hincapié en que el límite estaba en el mal uso de las doctrinas y que era necesario combinar la libertad de imprenta con la tolerancia religiosa. La aparición de una corriente de opinión a favor de la tolerancia religiosa fue lenta pero palpable. El llamado "Plan Beitia", la figura de José Joaquín Olavarrieta ("Clararrosa”) y Ramón de Salas abogaron claramente por una libertad de cultos que tardó en encontrar hueco en el interior no ya de la Iglesia, sino del panorama político. Habría que esperar a la década de los treinta para que, aunque débil, se dejara ver un territorio adecuado para el desarrollo de un incipiente catolicismo liberal. ${ }^{23}$

\footnotetext{
22 SANTillán, "La secularización de las creencias".

23 La PARra se ha ocupado de indagar los difíciles territorios de la tolerancia religiosa en el primer liberalismo español en "Intransigencia y tolerancia religiosa” y "Cultura católica: confesionalidad y secularización”, pp. 127-154.
} 
La experiencia mexicana de la exigencia de una tolerancia y libertad de cultos encontró en la figura de Vicente Rocafuerte su mejor expresión. No se trataba ya de aceptar la tolerancia como una exigencia de los tiempos, sino que la libertad económica y política reclamaba como corolario una libertad de cultos que tardaría décadas en lograrse, toda vez que la búsqueda del Patronato y el mantenimiento del Fuero dejaron a la Iglesia en un territorio intermedio entre viejo y nuevo régimen que sólo fue abordado de forma firme en la década de los cincuenta. ${ }^{24}$

La dinámica política de los dos liberalismos -el doceañista y el hispánico o mexicano - ${ }^{25}$ fue bastante semejante, no sólo por la influencia del liberalismo gaditano en las primeras décadas del siglo XIX, como muestra la Constitución de 1824, sino porque unos y otros deseaban reformar la Iglesia, adaptarla a la realidad de un régimen liberal constitucional, monárquico en España y republicano y federal en México, pero finalmente, los dos inequívocamente católicos. No cabe hablar de paralelismos, pero sí de una agenda en ambos liberalismos que no se alejó mucho de los tempos y modelos a aplicar. En la década de los treinta, en plena guerra carlista y en el momento en que se configuró definitivamente el liberalismo posrevolucionario en España, la reforma de la Iglesia se abordó desde dos posiciones: una moderada, que pretendía desarrollar la reforma eclesiástica de acuerdo con el Vaticano y las autoridades eclesiásticas españolas, y otra de carácter más radical que, ya desde la

24 Véase Santillán, “Tolerancia religiosa y moralidad pública”, pp. 87-104.

${ }_{25}$ Tomamos aquí la denominación de liberalismo hispánico de BREÑA, “Consideraciones sobre el liberalismo mexicano", pp. 37-66. 
legalidad, y con el apoyo de medidas extralegales de fuerte contenido anticlerical, forzó la reforma eclesiástica, la liquidación del diezmo y la desamortización de los bienes de la Iglesia. La primera propuesta casi coincide en el tiempo con las medidas de reforma eclesiástica desarrolladas en México por Valentín Gómez Farías, ya que se inicia con el gobierno del Conde de Toreno, que abre el régimen del Estatuto Real y tiene en Nicolás María Garelli su mejor representante. Su propuesta de abordar la reforma eclesiástica con el acuerdo de los religiosos se tradujo en la formación de una Junta Eclesiástica que se vio superada por la presión social, los movimientos anticlericales de 1834 y la llegada al poder de Mendizábal. ${ }^{26}$

Es cierto que las medidas desamortizadoras y la política religiosa de los liberales españoles fueron más lejos de lo que lo hicieron los liberales mexicanos. En España se produjo una ruptura con la Iglesia, en medio de una guerra dinástica y social (guerra carlista) que tuvo el apoyo masivo de las órdenes religiosas, provocando la ruptura con el Vaticano, a consecuencia de la política liberal, sobre todo, de la desamortización y la disolución de las órdenes religiosas en $1837 .{ }^{27}$ No fue sino hasta la vuelta de los moderados

\footnotetext{
${ }^{26}$ Véase el proceso en Revuelta GonZÁlez, La exclaustración.

27 El proceso se inició con el decreto de 19 de febrero de 1836, por el que se ponen en venta los bienes de las órdenes y corporaciones religiosas extinguidas; se sigue con el decreto de 8 de marzo de 1836 por el que se eliminan las corporaciones religiosas de clérigos regulares, una línea desamortizadora que se completó con una segunda disposición desamortizadora por ley de 29 de julio de 1837 que amplió la desamortización a los bienes del clero secular. El proceso se continuó bajo la regencia de Espartero (1840-1843) con la ley de 2 de septiembre de 1841. Sobre el marco legislativo véase el clásico de Tomás y Valiente, El marco político; sobre
} 
al poder en la década de 1844 a 1854 que se recompusieron las relaciones con el Vaticano con la firma del Concordato de $1851 .^{28}$

En México, las reformas eclesiásticas se desarrollaron en el marco de la afirmación de la soberanía del Estado, pero cuando aún no estaban establecidas de forma clara las competencias de los estados particulares y el federal. El regalismo y el intento de controlar a la Iglesia se percibieron claramente desde 1826, cuando se debatió en el Senado el derecho de la nación al Patronato sin consultar a Roma. ${ }^{29}$ Poco más tarde, primero Mora, a través de sus reflexiones sobre la naturaleza de la propiedad (1831), y después Gómez Farías, desde la vicepresidencia, abordaron la reforma de la Iglesia. Como en el caso de Mendizábal, Calatrava y los liberales españoles, el liberalismo mexicano (Gómez Farías, Mora, Zavala, etc.) abordó el papel de la corporación eclesiástica en el nuevo orden político desde tres dimensiones diferentes: el carácter económico y utilitarista del pensamiento liberal, ya que era necesario poner en circulación los bienes eclesiásticos para fomentar el progreso económico, al incorporarlos al mercado; otra, de carácter político y legal: la propiedad corporativa debía suprimirse a favor de un régimen de igualdad y uniformidad administrativa dentro del Estado; finalmente, por razones fiscales, ya que el

la desamortización de Mendizábal y Madoz, RuedA, La desamortización; Abós Santabárbara, La desamortización de Mendizábal a Madoz; para el proceso de reforma de las órdenes religiosas véase BARRIo Gozalo, "Reforma y supresión de los regulares en España”, pp. 89-118.

${ }^{28}$ Una síntesis del contenido y alcance del Concordato de 1851 en Alonso, La nación en capilla.

${ }^{29}$ Véase Martínez Albesa, La Constitución de 1857, t. II, pp. 723 y ss. 
Estado tenía una dificultad financiera y había que recurrir a los bienes eclesiásticos. ${ }^{30}$ Este recurso financiero fue muy común, como vemos, en los distintos países y estuvo, como ya se ha apuntado, entre las razones básicas por las que se llevó a cabo la desamortización de Mendizábal. En España, el factor político de buscar entre los adquirentes de bienes desamortizados un apoyo al régimen liberal fue central, como habría de verse también en México tras las Leyes de Reforma y la negativa del propio gobierno de Maximiliano a devolver las tierras desamortizadas. ${ }^{31}$

Una comparativa del proceso reformista en la década de los treinta nos muestra que la revolución española avanzó más que la mexicana, toda vez que Gómez Farías no pudo desarrollar su programa completo. En primer término, hay que resaltar que en México la reforma no trataba de eliminar los fueros y privilegios del clero, ni tomó medidas sobre las propiedades eclesiásticas, ni declaró la tolerancia religiosa ni la libertad de conciencia. Las medidas se centraron, entre otras, en el Patronato Real (30 de mayo de 1833), secularización de las misiones de las dos californias y prohibición de las obvenciones parroquiales (17 de mayo de 1833); reforma de la enseñanza pública (19 de octubre de 1833); clausura de la Real y Pontificia Universidad de México (19 de octubre de 1833); sometimiento de los seminarios al gobierno, estableciendo una Dirección General de Instrucción Pública; eliminación de la obligación civil del

\footnotetext{
30 Para el caso mexicano véase HaLe, El liberalismo mexicano, pp. 111 y ss. ${ }^{31}$ La posición de Maximiliano ante el problema de la desamortización y los intentos frustrados de lograr un concordato han sido analizados en detalle. Véase, García UGarte, Poder político y religioso, pp. 1061-1082; Martínez Albesa, Catolicismo y liberalismo, t. III, pp. 1961-2075.
} 
diezmo (27 de octubre de 1833); abolición del fuero militar y estímulo de las milicias cívicas (15 de noviembre de 1833), etcétera.

La cuestión de la no desamortización de las tierras de la Iglesia no significa que no se pensara en ello, toda vez que la Ley Agraria de Zacatecas de 1829 (después derogada) afectaba directamente a las tierras eclesiásticas. La fuerza de la Iglesia impidió ese proyecto. Como en el caso español ante la desamortización eclesiástica se formularon proyectos alternativos. Uno de carácter "ilustrado" y otro abiertamente liberal, de mercado. En España estos dos "modelos" fueron expuestos por Juan Álvarez Mendizábal y Álvaro Flórez Estrada. El primero, triunfante, contemplaba como objetivo prioritario resolver el problema de los vales reales y poner las tierras al servicio del mejor postor. Con ello se llevó a cabo en subasta pública la venta de los bienes del clero. Flórez Estrada, por su parte, defendía una fórmula distinta ya que contemplaba que las tierras desamortizadas fueran entregadas a campesinos que con un arrendamiento de largo plazo (tipo enfiteusis) conformaran una base social de pequeños propietarios arrendatarios.

En México, como bien sabemos, se propusieron también dos fórmulas cercanas. De un lado, Mora sostenía que los bienes debían quedar en manos de los arrendatarios. En su Disertación sobre la naturaleza y aflicción de las rentas y bienes eclesiásticos,... ${ }^{32}$ hizo hincapié en la naturaleza temporal y de origen civil de los bienes eclesiásticos. En este sentido, la Iglesia podía perder sus bienes sin necesidad de alterar su naturaleza espiritual. Podía, en definitiva,

32 Martínez Albesa, Catolicismo y liberalismo en México, t. II, pp. 852 y ss. 
ser desposeída de sus bienes por razones de utilidad pública. Por su parte, Lorenzo de Zavala, a semejanza de Mendizábal, consideraba prioritario amortizar la deuda pública nacional con los bienes del clero regular. ${ }^{33} \mathrm{La}$ aplicación de la reforma se hizo difícil, toda vez que la oposición a la misma se intensificó, como muestra la protesta del obispo de Puebla o la formación del movimiento "Religión y fueros" del coronel Ignacio Escalada. En la antesala de una posible guerra civil, Miguel Ramos Arizpe garantizó a los obispos que no se abandonaba la religión católica profesada por los mexicanos y la suspensión del Patronato que tanto molestaba a la Iglesia. Los eclesiásticos observaron con claridad que en el interior del liberalismo se producían dos corrientes bien distintas respecto de las reformas y de la propia concepción de México como Estado y nación. El sector más conservador se mostraba proclive al mantenimiento de los fueros eclesiástico y militar, así como al centralismo, en tanto que el liberal se pronunciaba abiertamente por el federalismo y la liquidación de los fueros. De momento, el fracaso de una política secularizadora, si se quiere anticlerical, que no antirreligiosa, representó un fortalecimiento del vínculo entre Iglesia, militares y aquellos sectores que estaban en contra de la transformación del orden social. La respuesta fue el fortalecimiento del centralismo y una radicalización conservadora que se concretó en el Plan de Cuernavaca y la llegada al poder de Antonio López de Santa Anna, como protector de "la santa religión, el ejército y el país". ${ }^{44}$

33 Un acercamiento a la posición de Zavala ante la religión en Trejo Estrada, Los límites de un discurso, pp. 346 y ss.

${ }^{34}$ Véase García Ugarte, "Liberalismo y secularización", pp. 68 y ss; 
La cristalización de dos opciones liberales en el México de los treinta estaba fraguada y empezaba a nutrir dos programas de gobierno, dos imaginarios de nación, donde Ejército e Iglesia constituían un baluarte frente al liberalismo más radical.

Hasta mediados de siglo, la tensión tanto en España como en México estuvo en la confrontación entre la confesionalidad del Estado y la intolerancia que mostraron las constituciones y una tímida e indirecta apertura hacia la tolerancia religiosa que se desprende de la Constitución española de 1837. En la década de los cuarenta, el dominio conservador representó un fortalecimiento de las posiciones de la Iglesia y, tras el fracaso de la regencia de Baldomero Espartero (1840-1843), se frenó la desamortización y negoció con el Vaticano un nuevo estatus que llevó al Concordato de $1851 .{ }^{35} \mathrm{El}$ Concordato representó un triunfo para la Iglesia bajo la protección de la derecha del Partido Moderado que, no conforme con la intolerancia religiosa sustentada por la Constitución de 1845, otorgó a la Iglesia amplias prerrogativas: confesionalidad del Estado, establecimiento de un presupuesto de culto y clero, autorización del establecimiento de tres órdenes religiosas, y la posibilidad, más adelante desarrollada, de establecer un dominio sobre la moral en la educación y el establecimiento de un sistema educativo bajo

Staples, "Secularización, Estado e Iglesia en tiempos de Gómez Farías", pp. 109-123.

${ }_{35}$ Para un análisis del tratamiento constitucional en la primera mitad del siglo XIX véase García García, Constitucionalismo español y legislación; para una síntesis de las negociaciones y acuerdos del Concordato de 1851 véase Alonso, La nación en capilla, pp. 200 y ss. 
control de la Iglesia que pocos años después legisló la Ley Moyano de $1857 .{ }^{36}$

\section{LA CONFRONTACIÓN ENTRE CONFESIONALIDAD Y SECULARIZACIÓN (1854-1874)}

Las medidas reformadoras de la primera mitad del siglo XIX no aspiraron a secularizar el Estado ni la sociedad, sino a reformar el papel de la Iglesia en el nuevo orden económico y social. En medio de la guerra carlista en España la reforma eclesiástica se produjo de una forma más intensa que en México, donde las medidas de los liberales se frustraron a partir de 1834. A comienzos de los años cincuenta, bajo el dominio del conservadurismo en México y España se fortaleció la intolerancia; en España bajo la firma del Concordato y el dominio del sector más reaccionario del moderantismo, en México bajo la dictadura de Santa Anna tras la derrota con Estados Unidos y la pérdida de casi la mitad del territorio. Ese dominio conservador y el hecho de que el papado iniciara una fase de dura confrontación con el liberalismo y las libertades modernas forma el suelo sobre el que en los dos países se produce un proceso revolucionario: el bienio progresista y la constitución nonata de 1856 que lleva a la aprobación constitucional de la tolerancia religiosa (art. 14), en tanto que en México tras la revolución de Ayutla se aprobó la Constitución de 1857, donde no se atendía de forma directa el tema, pero se desarrollaba indirectamente

36 Para una síntesis de las diversas leyes educativas de la España contemporánea véase Puelles Benítez, Educación e ideología. 
la tolerancia religiosa. ${ }^{37}$ Es el signo del tiempo la apertura de una nueva fase de confrontación entre los partidarios de la confesionalidad del Estado, la unión católica y la intolerancia religiosa, frente al sector del liberalismo que desde una concepción tolerante y progresista reclama, si no la plena libertad religiosa, sí, al menos, la tolerancia. Ese es el marco que está detrás de la Constitución de 1856 y del progresismo español y que, finalmente, se acabará imponiendo tras las Leyes de Reforma en México y el Sexenio Democrático que siguió a la revolución de 1868 en España.

En ambos casos fue necesaria una revolución y una confrontación abierta entre confesionales y librecultistas. Las Leyes de Reforma desarrollaron, y superaron, la política liberal de España en la década de los treinta. En cualquier caso, ni en España ni en México la legislación de Reforma o la de la revolución de 1868 fue anticatólica, sino simplemente anticlerical, en la medida en que pretendía garantizar la libertad religiosa y, en su caso, la separación de la Iglesia y el Estado. De forma directa la Constitución de 1857 fue suave en el tratamiento de la cuestión religiosa, pues evitó su regulación directa. ${ }^{38} \mathrm{La}$ fuerte oposición de la Iglesia y

37 Sobre los debates en las constituyentes hay una bibliografía abundante. Para una síntesis del tratamiento de la cuestión religiosa véase RoSelló Soberón, "Entre el sentido común católico y la opinión pública", pp. 217-260.

${ }^{38}$ Los debates se desarrollaron en torno al tratamiento que el artículo 15 debía dar a la religión. Tras los debates, la mayoría votó en contra y el tema religioso sólo se incorporó tras una adición que pasó a ser el artículo 123, que señalaba: "Corresponde exclusivamente á los poderes federales ejercer, en materias de culto religioso y disciplina externa, la intervención que designen las leyes". Véase Galeana, "La revolución cultural de la Reforma”, pp. 31 y ss. 
la fracción conservadora se centró en los artículos 3 (libre enseñanza), 5 (protección de la libertad del hombre), 6 (libre manifestación de las ideas), 7 (libertad de expresión y prensa), 9 (libertad de asociación), 12 (negación de títulos de nobleza) y otros que afectaban a los derechos de propiedad de las corporaciones, la soberanía popular, las facultades de Congreso y la atribución a los poderes federales para legislar en materia de culto religioso externo (art. 123). ${ }^{39}$ El resultado fue un abierto rechazo eclesiástico al juramento constitucional y la oposición directa al conjunto de leyes que desde Ayutla modificaron el statu quo de la Iglesia: Ley de Administración de Justicia de 25 de noviembre de 1855 (Ley Juárez); Ley de Desamortización de los Bienes de las Corporaciones Civiles y eclesiásticas de 25 de junio de 1856 (Ley Lerdo), que generó varios levantamientos bajo el lema "Religión y fueros"; decreto de apertura del Registro Civil de nacimientos (27 de enero de 1857); Ley de Obvenciones Parroquiales, de 11 de abril de 1857 (Ley Iglesias); que junto con la clausura de la Universidad Pontificia fueron las reformas adheridas al Plan de Ayutla. Las leyes posteriores (Leyes de Reforma) radicalizaron el proceso con la ley de nacionalización de los bienes eclesiásticos ( y de separación de la Iglesia y el Estado) de 12 de julio de 1879; ley de matrimonio civil del 2 de julio de 1859; Ley Orgánica del Registro Civil y Ley sobre el Estado Civil de las Personas de 31 de julio de 1859; el decreto sobre días festivos y prohibición de asistencia social a la Iglesia de 11 de agosto de 1859; Ley de Libertad de Cultos Religiosos del 4 de diciembre de 1860; decreto de secularización de los hospitales del

39 Véase Vega Gómez, “Ley sobre libertad de cultos”, pp. 269 y ss. 
2 de febrero de 1860 y el decreto de extinción de las comunidades religiosas de 26 de febrero de 1863. Estas medidas, desarrolladas en medio de la guerra, fueron incorporadas a la Constitución por Lerdo de Tejada mediante decreto de 25 de septiembre de 1873.

Desde Ayutla quedó de manifiesto que la división del liberalismo mexicano tenía tres sensibilidades: la conservadora, a favor de la unidad católica y de la plena adhesión a los intereses religiosos y corporativos de la Iglesia; la moderada, en defensa de un planteamiento tolerante, y aquella otra de filiación radical que apostaba por una creciente secularización del Estado y la sociedad. Dejando a un lado un sector reducido de laicismo radical, la posición predominante en la asamblea constituyente y la posterior legislación fue aquella que se asociaba con el catolicismo liberal, de figuras como Francisco Zarco, que eran declaradamente anticlericales, pero que al mismo tiempo se afirmó como católico, apostólico y romano. Más extrema se presentaba aquella posición de un liberalismo radical, en la línea de la sustentada por Ignacio Ramírez, El Nigromante, que se asociaba a un ateísmo que encuentra en España su corolario en la figura de Francisco Pi y Margall.

La lucha por la libertad religiosa y la separación de la Iglesia y el Estado en España se encuentra asociada a los procesos que llevaron a la revolución de 1868, a la aprobación de la Constitución de 1869 y, en su versión más radicalizada, a la experiencia de la Primera República y a la Constitución federal de 1873. Es en este periodo que se afirma la libertad religiosa y de cultos contemplada en el artículo 21 de la Constitución de 1869. En medio de una afirmación de los derechos de imprenta, de asociación, de reunión, la 
libertad religiosa ocupó uno de los debates más intensos de las constituyentes. Como en el caso mexicano, se observaron tres corrientes principales: la que se afirmaba sobre la unidad católica y la intolerancia religiosa, que defendieron los miembros de la Iglesia, los neocatólicos y los carlistas; la de confesionalidad del Estado, pero con tolerancia religiosa, del sector asociado al colectivo que se había formado en la Unión Liberal, y aquel otro que, aunque de carácter heterogéneo, se postulaba por la libertad religiosa y, en su versión más fuerte, por la separación de la Iglesia y el Estado. Es el momento en que católico liberales como Emilio García Ruiz y Emilio Castelar, entre los republicanos, y los krausistas, defendieron la separación entre ambas entidades. ${ }^{40}$ Pero también cuando en el marco de la experiencia de la Primera República un sector apostaba por una política de laicismo radical. ${ }^{41}$

La Constitución de 1869 trajo consigo la libertad religiosa, pero igualmente una guerra carlista en la que el tema de la religión constituyó un ingrediente decisivo, primero bajo la monarquía de Amadeo de Saboya (1871-1873) y más tarde, en el marco de una república federal que se abrió de una forma decisiva a la secularización del Estado. Advenida por el fracaso de la monarquía saboyana, la República mostró en España la pluralidad que liberales, demócratas y republicanos ensayaron ante el tema de la religión, de la Iglesia y de las relaciones entre Estado e Iglesia. El Sexenio

\footnotetext{
40 La cuestión religiosa en el Sexenio ha sido objeto de una amplia atención de la historiografía. Véase Perlado, La libertad religiosa; Petschen, Iglesia-Estado; CÁRcel ORTí, Iglesia y revolución en España; MARTí Gilabert, La cuestión religiosa; Pérez Ledesma, "Estudio preliminar”. 41 Suárez Cortina, Entre cirios y garrotes, pp. 125-152.
} 
Democrático marca una línea divisoria entre dos momentos de fuerte contenido confesional: la era isabelina y la Restauración. Fue el momento histórico en el que los católico liberales tuvieron ocasión, pronto cercenada, de afirmar sus principios y cuando la libertad de cultos mostró que sus adversarios hicieron de la religión y la unidad católica un frente de lucha que alcanzaba al antiguo partido moderado y al tradicionalismo que, separados por razones de la legitimidad dinástica y el rechazo carlista a la monarquía constitucional, sin embargo, estaban firmemente unidos por la concepción de que España como tal debía su ser a la tradición católica. ${ }^{42}$

La confrontación entre confesionalidad y libertad religiosa se acentuó en la misma medida en que la Iglesia apostó por el antiliberalismo y los sectores conservadores por asociar catolicismo y nación en una versión dogmática de afirmación de una unidad católica que, como máximo, aceptaba una tímida tolerancia religiosa. En México, el liberalismo buscó alternativas a esta situación a partir del intento de crear una Iglesia nacional. ${ }^{43}$ En España, tras la firma del Concordato, las luchas de los liberales pasaron por garantizar la libertad religiosa y, en sus versiones más extremas, por desarrollar un duro anticlericalismo que buscaba la secularización ya del Estado, ya de la sociedad. En todo caso, el panorama de las relaciones Iglesia-Estado hubo de conocer

${ }^{42}$ Louzao, "Nación y catolicismo”, pp. 65- 89.

43 Sobre ese proyecto véanse Pérez Montfort, "Nacionalismo, clero y religión", pp. 39-76; CrANE, "La formación de una iglesia nacional mexicana”, pp. 105-120; para la expansión del protestantismo desde la década de los setenta véase García Ugarte, Poder político y religioso, t. II, pp. 1463 y ss. 
en los dos países una reformulación en las décadas finales del siglo XIX.

\section{LA INFLEXIÓN CONSERVADORA Y LA RECUPERACIÓN} ECLESIÁSTICA: RESTAURACIÓN Y PORFIRIATO (1876-1900)

A comienzos de la década de los setenta, en México y España se formularon las posiciones más firmes del liberalismo anticlerical en la constitucionalización de las Leyes de Reforma por parte de Lerdo de Tejada y el proyecto de separación de la Iglesia y el Estado por parte del federalismo en 1873. Frente a ambos se produjo una clara reacción conservadora que podríamos caracterizar de estabilidad posrevolucionaria. En Tuxtepec, Porfirio Díaz se levantó contra la República Restaurada; en Sagunto, Martínez Campos lo hizo contra la República unitaria del general Serrano. El resultado fue el nacimiento de dos regímenes que revisaron los fundamentos y prácticas políticas del liberalismo democrático. Ambos sistemas representaron una corrección de los modos y maneras del sistema desarrollado durante la República Restaurada y el Sexenio democrático. En el terreno de la religión y de las relaciones entre la Iglesia y el Estado, con sus diferencias específicas, se observó una recomposición y fortalecimiento de la Iglesia en ambas experiencias. ${ }^{44}$

En el caso español, el triunfo restaurador en la figura de Alfonso, hijo de Isabel II, fue obra de Antonio Cánovas del Castillo, que desarrolló un sistema establecido sobre la

44 Sobre una perspectiva comparada de la restauración y el porfiriato véase Suárez Cortina, “Élites, ciencia y política”, pp. 203-234. 
base de la soberanía compartida, la monarquía constitucional y la confesionalidad del Estado. En el mexicano, Porfirio Díaz respetó formalmente la Constitución de 1857, el sistema federal y la separación de la Iglesia y el Estado, pero desarrolló una política de conciliación que facilitó la recuperación y el desarrollo de la Iglesia desde los años ochenta. Ésta vino facilitada, en primer término, por el impulso que Labastida dio a la participación política desde su vuelta de Roma en 1871 y, sobre todo, como reacción a la política anticlerical que llevó la incorporación a la constitución de la separación de la Iglesia y el Estado, el establecimiento del matrimonio como contrato civil, la prohibición de adquirir bienes raíces y capitales a las instituciones religiosas y la eliminación del juramento religioso. Por otro lado, la eliminación de la enseñanza religiosa en las escuelas públicas representó una fuerte amenaza para la supervivencia del poder eclesiástico en la sociedad, frente al auge del positivismo y la paulatina entrada de protestantes en ciudades y haciendas. ${ }^{45} \mathrm{Al}$ mismo tiempo, como ha recordado Marta Eugenia García Ugarte, la presencia de las escuelas protestantes fue muy poco relevante, ante la doble dinámica de los liberales de establecer una formación asentada sobre el positivismo y la de la Iglesia que buscaba fomentar la gestación de un ciudadano católico en competencia con el anterior.

El porfiriato no representó el abandono de la escuela positivista que había forjado desde 1867 Gabino Barreda. Positivistas fueron Sierra y su entorno, y los científicos constituyeron un baluarte muy reconocible dentro

${ }^{45}$ Sobre el papel del protestantismo véase Bastian, Los disidentes; para el caso español, Vilar Ramírez, Intolerancia y libertad. 
del entramado porfirista, como bien ha ilustrado Charles Hale. ${ }^{46}$ Con todo, la pugna por la imposición de determinados textos escolares puso de manifiesto la confrontación y correlación de fuerzas entre los liberales espiritualistas y el positivismo, tal y como mostraron los debates sobre el método (1877) y de lógica entre los manuales de Alexander Bain y Guillermo Tiberghien. ${ }^{47}$ La Iglesia, por su parte, aprovechó la tolerancia del sistema para ocupar espacios hasta entonces vetados. Frente a una política de contención, a la defensiva, en tiempos de la Reforma, ahora la Iglesia se mostraba abierta a disputar al liberalismo su espacio social. Es el tiempo de León XIII, cuando el programa de recristianización y de la formación de diversas iniciativas sociales se apoyó en México en la política de conciliación de Porfirio Díaz y en España en un canovismo que, superada la disputa por la unidad católica, encontró en la Iglesia y en el Vaticano unos de sus asociados más firmes. ${ }^{48}$ Para este cometido, la Iglesia actuó en cada país acomodándose a las circunstancias históricas. En México no fue necesario cambiar la constitución federal, sino las prácticas políticas, desarrollando una centralización y unos mecanismos informales que marcaron el componente de un liberalismo autoritario que centró su interés en el control político y social de las oligarquías estatales y el desarrollo económico.

La política religiosa del canovismo se centró en la superación de la unidad católica y en el reconocimiento de la

\footnotetext{
${ }^{46}$ Hale, La transformación del liberalismo.

47 Illades ha dado cuenta de estos debates en "Ciencia y metafísica en el siglo XIX", pp. 69-114.

48 Revuelta González, Insurrección o legalidad; Revuelta González, "La recuperación eclesiástica y el rechazo anticlerical”, pp. 213-234.
} 
tolerancia religiosa. La constitución de 1876 contemplaba la confesionalidad del Estado y la tolerancia de otros credos en su dimensión privada, no pública. A diferencia de México, donde los católicos cercanos al Papa mostraron una unidad razonable, en España estuvieron divididos por razones políticas, ya que el carlismo y el integrismo no aceptaron los planteamientos de la monarquía constitucional, obligando al propio Papa a publicar una encíclica Cum multa, destinada a superar la división entre los católicos españoles. ${ }^{49}$ La división entre los católicos españoles contrasta con la unión de los mexicanos. Y allí donde éstos pudieron formar un partido católico, en España resultó imposible..$^{50}$ La cuestión religiosa en España estimuló la división política ya que en la década de los ochenta, la formación del integrismo constituyó un ingrediente de intolerancia religiosa que rechazaba cualquier distinción entre política y religión.

En cualquier caso, más allá de esta diferencia, y de la intensidad que la recuperación católica tuvo en cada lugar, Restauración y porfiriato representaron un periodo de recuperación eclesiástica. En México la política de conciliación permitió a la Iglesia recuperar protagonismo y visibilidad social. Se produjo un relajamiento de las normas, se autorizaron o toleraron los toques de campanas, el uso de indumentaria religiosa en las calles, se toleraron conventos de monjas de forma discreta, la Iglesia pudo adquirir propiedades..., en fin, una recuperación creciente que llevó a ésta a reclamar a comienzos del siglo xx una suspensión de las

49 Robles Muñoz, “La Cum multa de León XIII”, pp. 297-348; para el movimiento católico véase MonTERo, El movimiento católico en España. 50 Véase Correa, El Partido Católico Nacional; O’Dogherty Madrazo, De urnas y sotanas, pp. 192-236. 
Leyes de Reforma. El procedimiento, como ha mostrado Ricardo Cannelli, fue la intermediación de un sector de la Iglesia representado por Eulogio Gillow, el obispo de Oaxaca, con quien Porfirio Díaz desarrollaba sus planes de intervención indirecta en los asuntos eclesiásticos. Esa recuperación, tenue bajo el porfiriato, se hizo mucho más visible en la España de las últimas décadas del siglo Xix. Como en México, el catolicismo social asumió un protagonismo creciente, pero el apoyo declarado del conservadurismo se dejó sentir no sólo en el plano político, sino en el educativo y en la ocupación creciente del espacio público. La respuesta liberal no fue otra que acentuar su discurso secularizador y mostrar una clara confrontación con el clericalismo que llevó a un enfrentamiento abierto tras el fin de siglo. ${ }^{51}$

A la altura de 1900, el resultado era la visibilidad, reiterada, de que en la historia política de los dos países se formularon dos proyectos nacionales que tuvieron una percepción muy distinta del papel de la religión en los asuntos públicos. Sin ánimo de simplificación, cabe señalar unas líneas maestras en torno a la relación entre religión y política: aquella establecida por los conservadurismos ${ }^{52}$ de fuerte impregnación religiosa y de defensa de la confesionalidad del Estado, y aquella otra, de signo más liberal, que no rechazaba la religión, pero que mostraba una exigencia de separación entre las instancias política y religiosa. En el interior de cada una

51 Una visión de conjunto de los conflictos entre clericalismo y anticlericalismo en Cueva y Montero, "Clericalismo y anticlericalismo".

${ }^{52}$ Erika Pani ha ofrecido un panorama global de la construcción y manifestaciones de un pensamiento conservador en México. Véase PAni (coord.), Conservadurismo y derechas en la historia de México; para el caso español véase GonZález Cuevas, Historia de las derechas en España. 
de estas corrientes se produjeron modalidades, pero en todo caso cabría resaltar que la primera fue clerical y la segunda, declaradamente anticlerical. No es de sorprender, pues, que desde el nacimiento del Estado-nación en España y México se generaran discursos alternativos de nación: el conservador y el liberal, y que el papel de la religión en ellos fuera un elemento distintivo de primer orden. Tan de primer orden que en el marco del dominio de los distintos conservadurismos mexicano y español, el papel de la religión fue creciente, como muestran la consagración de México a la Virgen de Guadalupe (1895), y de España al Sagrado Corazón de Jesús (1919). También, y en sentido contrario, que el anticlericalismo, cuando no incluso la antirreligiosidad, constituyen marcos de identidad del proyecto de nación liberal. ${ }^{53}$

De todos modos, el alcance del guadalupismo en México desborda el que en España presentan la Virgen de Covadonga, la del Pilar o el caso del apóstol Santiago. Aunque Santiago es el patrón de España y su mística remite a la reconquista - recuérdese su estampa a caballo y con espada-, su alcance no llega al que en México tiene la Virgen de Guadalupe, aceptada por los historiadores como el fundamento histórico de la construcción de la nación mexicana, una vez que, considerada ya patrona de la Nueva España, su imagen era el icono de la identificación entre el reino y sus pobladores, tanto criollos como mestizos e indígenas. Como ha recordado Renée de la Torre, a lo largo de la historia de México se desarrolló un sincretismo entre viejas y nuevas devociones, en las que la Virgen de Guadalupe ejerció una

53 Cueva Merino y Montero, "Clericalismo y anticlericalismo entre dos siglos" pp. 121-120. 
triple función: integrar y mestizar culturas, imponer dominio cultural, resistir desde lo popular y renovar las tradiciones de cara al presente. Se trata, pues, del símbolo más potente de la identidad cultural mexicana, por encima del proceso de secularización del Estado. ${ }^{54}$

DISCURSOS CONSERVADOR Y LIBERAL DE NACIÓN: NACIONAL CATOLICISMO Y ANTICLERICALISMO

Como ha señalado de forma reiterada la historiografía dedicada a los procesos de nacionalización, una cosa es la construcción del Estado y otra la de la nación. Construir naciones remite no sólo a procesos políticos, militares y legislativos; se ocupa de aquellos marcos culturales destinados a dotar de identidad a los distintos proyectos. Tradiciones culturales, mitos, discursos diversos de nacionalidad se fueron desarrollando para articular ese artefacto cultural y simbólico que es la nación. En el caso de los discursos de nación que en España y México se generaron en el siglo XIx, tras la quiebra de la monarquía católica, podemos distinguir con toda claridad dos principales: el conservador y el liberal. En ellos el papel de la religión constituyó un ingrediente diferencial básico.

No se trata de decir que los liberales no fueran católicos tanto en México como en España, sino que no hicieron de la naturaleza católica el centro de su discurso de nación. En cierto sentido, excepción hecha de minorías que podían adscribirse a otros credos o que se postulaban por un indiferentismo religioso, los liberales españoles y mexicanos fueron

54 Torre, "Los símbolos y la disputa”, pp. 17-38. 
claramente católicos, pero en el discurso de nación su papel fue muy distinto. En los elementos distintivos de ambos discursos ocuparon un papel diferencial temas culturales como el papel de la raza, el de la tradición, el de la religión y, sobre todo, en el caso de México, la relación con España, su papel como colonizador y las adscripciones que se le adjuntaron al hecho de "ser español". Como ha mostrado Tomás Pérez Vejo, ${ }^{55}$ en el caso mexicano la construcción del otro, entre la minoría criolla y lo español, constituía un problema no de fácil solución, dado el origen español de aquéllos. En todo caso, a lo largo de las décadas que siguieron a la independencia, la construcción de los dos discursos de nación se fue clarificando por medio de esos registros: la raza, la colonia, lo español y la religión, entre otros de carácter tal vez menor. En el caso de los discursos de nación de la España del siglo xix la religión tuvo también un papel central. Tampoco se puso en cuestión la naturaleza católica de los españoles, pero sí el tema de la intolerancia, de la definición nacional y el papel que a la tradición de tolerancia religiosa se le dio para diferenciar a conservadores y liberales. Una dicotomía rudimentaria, pero útil a efectos prácticos marca los discursos de nación de los moderados y los conservadores, afectos al catolicismo tradicionalista, a la identificación de España con la tradición católica, y a los liberales de signo progresista que alcanzaría a los republicanos, en la medida en que vieron en la pluralidad, o al menos en la tolerancia religiosa, el elemento que identificaba a España como nación.

${ }^{55}$ Véase Pérez Vejo, España en el debate público mexicano. 


\section{Patriotismo católico: la nación en el discurso conservador}

La primera nota que conviene resaltar al hablar de los ideales y discursos de nación del conservadurismo español y mexicano es que en el terreno cultural hubo una fuerte afinidad entre discurso nacional católico y conservadurismo liberal. Quiere esto decir que, aunque en el terreno del discurso de nación, por ejemplo, en España, hubo mucha identidad entre un amplio sector del tradicionalismo y el moderantismo, no dejó de significar que los moderados no fueran igualmente liberales, pero de un liberalismo adscrito a la filosofía del doctrinarismo que adquirió formas diversas; en unos casos a través del doctrinarismo francés (Chateaubriand, Guizot, Cousin), en otros claramente al caso inglés (Burke). Unos y otros fueron liberales, defensores de un liberalismo doctrinario que hizo de la monarquía constitucional su marco político básico. Se separaron, pues, de los tradicionalistas, en que éstos rechazaban en el plano político las concepciones de la monarquía constitucional, pero fueron afines en el terreno de la cultura y en el papel de la religión católica como el referente básico de la construcción de España como nación. Su marco de unión estuvo, primero, en la defensa de la unión católica, en la tentación de rechazar cualquier tolerancia religiosa y en identificar a España con una tradición católica que partía de los reyes godos y la conversión de Recaredo, ${ }^{56}$ la monarquía de Isabel y Fernando

${ }^{56}$ El carácter simbólico de Recaredo fue un elemento importante en el discurso nacional del tradicionalismo. Véase CANAL, "Recaredo contra la revolución”, pp. 209-230; la reconquista, Santiago, Covadonga, el Pilar, constituyeron referentes de esa dimensión nacional católica que movió a lo largo de los siglos xix y xx al catolicismo español. Para la Virgen del 
y el Concilio de Trento. En su imaginario, la ruptura entre monarquía católica y monarquía constitucional no era otra cosa que la adaptación a los tiempos, pero que veía establecida su continuidad en la soberanía compartida de rey y cortes, en el rechazo de la soberanía nacional y en los planteamientos recogidos en el Concordato de 1851, que consolidaba aquella ciudadanía católica que registraba la Constitución de 1812. Superada la cultura doceañista, propia de una fase revolucionaria, la tradición católica emergía como el centro de una nación que reconocía su ser sólo en cuanto que católica. Su trayectoria fue larga y desde 1808 los discursos de catolicidad para la nación fueron reiterados. Los encontramos en Jaime Balmes, en tradicionalistas como Cándido Nocedal y, más tarde, en Juan Vázquez Mella, o en figuras tan significativas del conservadurismo como Marcelino Menéndez y Pelayo. Su confrontación con el discurso liberal de nación se hizo especialmente vivo en el marco de los debates parlamentarios de las constituyentes de 1869, cuando Vicente Manterola y Emilio Castelar debatieron sobre la naturaleza de la religión y su papel en el reconocimiento de la libertad religiosa. Como recogió en aquellos momentos José Antonio Ortiz de Urruela:

La unidad nacional de España jamás se hubiera llevado a efecto sin el influjo y la intervención de la Iglesia y la religión católica. Aún en principios de este siglo, en una época en que tan lastimosamente se había rebajado la altivez y nobleza del carácter español, bajo la mortífera presión de un poder a la vez

Pilar véase Ramón Solans, La Virgen del Pilar dice...; Álvarez Junco ha hecho un detallado recorrido por los discursos de nación del pensamiento católico y conservador en Mater dolorosa, pp. 305-498. 
despótico y medio volteriano; la Iglesia y al catolicismo salvaron la independencia nacional; mientras que por carecer de esta cooperación de la Iglesia y de la fe las otras naciones del continente habían perdido su independencia. ${ }^{57}$

La independencia, y por ello la existencia de España como nación, estaba sometida, pues, al hecho de su catolicidad. ${ }^{58}$ Esta lectura de la relación entre pasado católico, preservación de la unidad católica y existencia de la nación fue la constante que movió al sector nacional católico, que, ya desde sus postulados políticos constitucionales, ya desde los que sostuvieron el tradicionalismo antiliberal, compartieron, sin embargo, la identidad de España como nación en su ser católico. Cuando años más tarde Marcelino Menéndez y Pelayo, en su Epílogo a la tercera edición de los Heterodoxos (1882), publicó su conocido texto de identidad entre nación y catolicismo, trabajaba ya sobre una base firme construida por una larga tradición de autores - religiosos o no- que daban fuerza a su argumentario:

Esta unidad se la dio a España el cristianismo. La Iglesia nos educó en sus pechos con sus mártires y confesores, con sus padres, con el régimen admirable de sus concilios. Por ella

57 OrTIZ de URruela, La Iglesia católica y la revolución de septiembre, pp. 13-14.

${ }^{58}$ Las relaciones entre conservadurismo, catolicismo e Iglesia fueron constantes, pero no podemos simplificar esa relación. En España es perceptible una clara distinción entre el moderantismo, defensor de la unidad católica y la intolerancia religiosa, y el conservadurismo liberal, igualmente católico, pero defensor de la compatibilidad de la confesionalidad del Estado y la tolerancia religiosa. La primera, como sabemos, caracteriza la era isabelina (1843-1868); la segunda, la Restauración (1875-1923). 
fuimos nación, y gran nación, en vez de muchedumbre de gentes colecticias, nacidas para presa de la tenaz porfía de cualquier vecino codicioso. No elaboraron nuestra unidad de hierro de la conquista, ni la sabiduría de los legisladores; la hicieron los dos apóstoles y los siete varones apostólicos. ${ }^{59}$

Este discurso de identidad entre catolicismo y nación llevó a una lectura del pasado cargada de distorsiones, donde la presencia durante ocho siglos de la cultura musulmana se convertía en la antiespaña, porque España lo era en tanto que católica y, en consecuencia, monárquica. Las posiciones que mostraran una línea discursiva ajena a estos elementos serían versiones más o menos modernas de la antiespaña, porque en momentos de crisis interna, la amenaza contra esa tradición habría de leerse en términos de cruzada. La experiencia española de los años treinta así lo muestra al identificar monarquía, nación y catolicismo como una trilogía amenazada por aquella otra del laicismo, la república y la antinación.

El discurso de nación de los conservadores mexicanos no puede identificarse, sin más, con el de los españoles, pero guardan varios puntos de conexión que merece la pena resaltar. En primer término, los conservadores mexicanos, a diferencia de los liberales, exaltaron la tradición española que arrancaba de la conquista, de la colonia y del bagaje histórico que representaba Nueva España. El análisis del conservadurismo y su imaginario nacional ha sido objeto de acercamientos múltiples - Pérez Vejo, Fowler, Morales

${ }^{59}$ Menéndez y Pelayo, "Epílogo" a Historia de los heterodoxos españoles, p. 39. 
Moreno, Pani, Zepeda - y ha mostrado la fuerte confrontación que liberales y conservadores trabaron sobre la construcción nacional y el papel de la colonia en la misma. La figura de Lucas Alamán, por un lado, y la de Carlos María Bustamante, por otro, ejemplifican ese debate en la primera mitad del siglo xIx. Para Alamán, la nación mexicana se fundaba en la llegada de los españoles y Nueva España constituía el bagaje fundamental de una herencia que se identificaba con Dios (catolicismo), rey (monarquía) y patria mexicana. Sin defender una vuelta a la Nueva España, sin embargo, reclamaban la preservación de la tradición hispánica, el mantenimiento de las corporaciones y una monarquía que representara unidad y gobierno fuerte, esto es, centralización. En todo caso, como muestra la figura de Alamán, el conservadurismo mexicano constituyó una fracción del propio liberalismo, aunque la dicotomía entre liberales y conservadores enmascarara los componentes liberales de su pensamiento político. ${ }^{60}$

Su lectura del pasado resaltaba que la unidad de México sólo había sido conseguida por la conquista y por lo tanto a ella se debía el ser de México como nación y, sobre todo, la prosperidad que se asociaba con Nueva España. Religión, lengua, usos y costumbres, ley y orden venían asociados a la presencia de España y, con ello, la identidad entre tradición hispánica y nacionalidad fueron elementos básicos de su imaginario nacional. La independencia había llegado por lógica evolución de los tiempos, más que por una lucha contra el dominio colonial y la restauración del pasado

${ }^{60}$ Véase Gómez OchoA, “Conservadurismo político y catolicismo en España”, pp. 327-364. 
prehispánico. La independencia de 1821 y Agustín de Iturbide representaban la construcción de una nueva nacionalidad sin ruptura, en la línea desarrollada por el pensamiento de Burke, tan afín a los ideales de Alamán. El Plan de Iguala - religión, independencia y unidad - representó el símbolo de ese nuevo artefacto nacional - México- que era distinto, pero no adversario de la tradición hispánica. Se trataba de una relación de filiación entre el viejo orden de la Nueva España y el nuevo de un México independiente que no rechazaba la historia colonial, sino que se establecía sobre su existencia. Como señalaba el propio Alamán en su carta a Santa Anna en 1853:

Es el primero conservar la religión católica, porque creemos en ella, y aun cuando no la tuviéramos por divina, la consideramos como el único lazo común que une a todos los mexicanos, cuando todos los demás han sido rotos, y como lo único capaz de sostener la raza hispanoamericana y que puede librarla de los grandes peligros a que está expuesta. Entendemos también que es menester sostener el culto con esplendor y los bienes eclesiásticos, y arreglar todo lo relativo a la administración eclesiástica con el Papa [...].

Deseamos que el gobierno tenga la fuerza necesaria para cumplir con sus deberes, aunque sujeto a principios y responsabilidades que eviten los abusos.

Estamos decididos contra la federación, contra el sistema representativo y por el orden de elección que se ha seguido hasta ahora; contra los ayuntamientos electivos y contra todo lo que se llame elección popular mientras no descanse sobre otras bases. ${ }^{61}$

${ }^{61}$ Recogido por ZepedA, Enseñar la nación, pp. 52-53. 
El programa conservador, de catolicismo oficial, centralización y rechazo de los planteamientos adscritos a la soberanía de la nación, representa un paralelo bastante cercano al que en España desarrollaron, primero los moderados, y más tarde, los conservadores. Su imaginario de nación se alejaba abiertamente de aquel otro que tanto en España como en México sustentaron los liberales. Los primeros se mostraron cercanos al catolicismo oficial y a los intereses de la Iglesia; los segundos, también católicos en su mayoría, sin embargo, fueron declaradamente anticlericales.

El discurso liberal de nación. Catolicismo y libertad: entre la tolerancia religiosa y el laicismo

El hecho de ver en el anticlericalismo un elemento de identidad propia del progresismo y de los sectores más radicales del liberalismo no representa que éstos se alejen de la religión como tal. En cierto modo, el único territorio donde parece haber acuerdo entre las lecturas de nación de los liberales y los conservadores es en torno al papel de la religión católica como un ingrediente de la identidad nacional española y mexicana. Así se puede observar en el caso de Morelos e Hidalgo, y también en el liberalismo de la primera mitad del siglo XIX, donde el papel de la Iglesia no se vio cuestionado hasta los tiempos de las Leyes de Reforma. Tampoco entonces dejó de percibirse el catolicismo como tal religión de los mexicanos, sino el papel de Iglesia como corporación y la necesidad de establecer una clara separación de las instancias política y religiosa, entre el Estado y la Iglesia.

En cualquier caso, es evidente que los liberales españoles y los mexicanos concibieron la nación desde supuestos 
históricos, religiosos y políticos distintos del conservadurismo. Es reconocible todavía una línea de intolerancia en Morelos, como lo fue en los constituyentes gaditanos, cuando se estableció la intolerancia religiosa como elemento garantizado por la Constitución. Pasada esa fase inicial de intolerancia religiosa los liberales españoles, dentro siempre del catolicismo, establecieron una mirada distinta sobre la identificación entre catolicismo y nación. En primer término, establecieron una apertura hacia la tolerancia religiosa que tuvo alcances múltiples. En el orden histórico representaba una recuperación de la Edad Media, en la que, a pesar del catolicismo de España, en plena reconquista, sin embargo, se hacía hincapié en la convivencia de credos, cuando España era un mosaico de culturas con musulmanes, judíos y católicos. El catolicismo era un elemento importante en la identidad nacional, pero no el único. Su planteamiento derivaba de esa tradición de tolerancia que habría de nutrir las constituciones españolas de 1856, con la tolerancia de cultos y, sobre todo, la de 1869 , con la libertad religiosa y la libertad de cultos. El derivado natural de este planteamiento no era otro que una cultura anticlerical, que no rechazaba la religión, pero que la ubicaba, en el mejor de los casos, en el terreno de la conciencia individual y en la defensa jurídica de la libertad religiosa.

La identidad nacional liberal se asociaba tanto a la aceptación de que España era un país de dominio católico, como a la necesaria apertura a la tolerancia religiosa y, sobre todo, el anticlericalismo liberal marcaba la distancia con el nacional catolicismo. Fue así, en 1834-1836, con la política desamortizadora, pero sobre todo con la matanza de frailes en el verano de 1834; se repitió más tarde, en el Sexenio 
Democrático y alcanzó su esplendor en la primera década del siglo xx cuando, tras la derrota colonial, el anticlericalismo devino tanto en programa de Gobierno (José Canalejas) como en un instrumento de movilización popular que en sus formulaciones más extremas alcanzó manifestaciones sacrofóbicas, como en el verano de 1909. ${ }^{62} \mathrm{La}$ constante liberal de radicalizar el discurso democrático y persistir en manifestaciones anticlericales es un referente central del imaginario nacional de la tradición liberal española que alcanzó en muchos sentidos al propio republicanismo español. ${ }^{63}$

Ese anticlericalismo es el mismo que encontramos en el México de medio siglo, cuando las Leyes de Reforma reubicaron a la Iglesia en el nuevo orden liberal. El discurso de nación liberal mexicano se alejaba del conservador de forma clara en el tema religioso, pero no menos en el modo en que interpretaron y utilizaron la experiencia colonial, su historia y la recuperación de la tradición prehispánica como un ingrediente básico de su identidad nacional. Conviene, no obstante, resaltar que antes de la Reforma, no hubo excesivas diferencias en el tratamiento que liberales y conservadores dieron a la idea de nación. Es cierto que ya se percibía una distancia entre Iturbide y su proyecto y Morelos y los insurgentes respecto del tema de la recepción de la cultura prehispánica y la raza que formaba la nueva nación. Pero

${ }^{62}$ Sobre la Semana Trágica y sus diversas manifestaciones véase ULLMan, La Semana Trágica; una síntesis en SuÁrez Cortina, "Entre cirios, barricadas y bayonetas", pp. 25-50.

${ }^{63}$ Véase SAlomón Chéliz, "El discurso anticlerical en la construcción de una identidad nacional", pp. 485-498; "Construir la identidad nacional”, pp. 99-111; sobre la identidad nacional y el republicanismo véase Álvarez Junco, "Republicanismo radical y españolismo", pp. 67-84. 
en aquellos momentos el tema confrontaba en torno a un mayor o menor centralismo y unos y otros no se plantearon socavar por completo el papel de la Iglesia y la religión en la nueva sociedad independiente. Hasta que las Leyes de Reforma acentuaron esa distinción puede hablarse de diferencias de grado, pero no de una gran confrontación entre ambos proyectos de nación. En cierto modo el liberalismo de ambos había bebido de Benjamín Constant y de Gaspar Melchor de Jovellanos. Cabría decir que hasta la década de los cuarenta hubo cierta cultura compartida por el liberalismo mexicano y que fue entonces cuando se radicalizó en dos direcciones opuestas el liberalismo: hacia una identidad entre México, españolidad, centralismo y catolicismo, frente a una recuperación del pasado azteca, del federalismo y de un liberalismo de fuertes componentes laicistas.

Es entonces cuando se hace dual de una forma evidente ese discurso de confrontación entre liberales y conservadores. Aun siendo igualmente católicos, los liberales, sin embargo, rechazaron abiertamente el corporativismo que sostuvieron los conservadores. Con distintas gradaciones ese fue el pensamiento de Juárez, Arriaga, Prieto, Zarco y aquellos que, desde el interior del catolicismo, sin embargo, postularon el lema "Dios y libertad", claramente confrontado con el nacional catolicismo de los conservadores. Incluso un católico apostólico romano como Zarco defendió la tolerancia religiosa. ${ }^{64}$

El proyecto liberal desde las Leyes de Reforma se propuso la construcción de una nación secularizada, donde

64 Véase, en este sentido, Bautista García, Las disyuntivas del Estado y de la Iglesia, pp. 46 y ss. 
la Iglesia fuera ajena a los asuntos del Estado. Es así que tanto el intento de formación de una Iglesia nacional, como la apertura a nuevos credos como el protestantismo, era inimaginable entre los conservadores. Al igual que los sectores más laicistas del liberalismo y republicanismo español, liberales como Ignacio Ramírez, o en España Francisco Pi y Margall y los federales, se abrieron a nuevas experiencias religiosas: unas de carácter deísta, como el librepensamiento, ${ }^{65} \mathrm{o}$ en su versión más firme la aparición del espiritismo, cuando no directamente una posición agnóstica o atea como la defendida por el propio Pi y Margall. ${ }^{66}$ El desarrollo de estas afinidades entre los laicismos español y mexicano se escapa a los cometidos centrales de estas páginas, pero muestra cómo los umbrales de laicidad a que apunta para Francia Bauberot, son aplicables a España y México, como ya ha hecho Jean Pierre Bastian. ${ }^{67}$

\section{A MODO DE CONCLUSIÓN}

Como se ha recogido más arriba, siendo la española y la mexicana dos sociedades declaradamente católicas, y habiendo desarrollado sus regímenes nacionales bajo la forma de república en México y de monarquía constitucional en España, abordaron, sin embargo, desde perspectivas muy distintas la relación entre Estado, Iglesia y nación. La secularización del Estado mexicano por los liberales federales, perfectamente compatible con la catolicidad de sus ciudadanos, se estableció

\footnotetext{
${ }^{65}$ Véase Álvarez Lázaro, Masonería y librepensamiento.

${ }^{66}$ SuÁrez Cortina, "Federalismo, religión y política en el siglo XIX", pp. 37-76.

${ }^{67}$ Bastian, “Leyes de Reforma”, pp. 141-164.
} 
desde la base de la libertad y pluralidad religiosa, al tiempo que el liberalismo español mostraba una defensa de la religión y de los intereses de la Iglesia que se consolidó bajo la hegemonía de los liberales moderados con el Concordato de 1851. Ha sido, pues, el dominio conservador en España el que se afirmó sobre la defensa del catolicismo y de la construcción de un ideal nacional de base católica. Un discurso nacional católico muy cercano al sustentado en México por la corriente conservadora. Ambos grupos se vieron fortalecidos por la fuerza de la tradición católica, por la experiencia colonial y por el rechazo de la tolerancia religiosa.

El contraste de este planteamiento estuvo sustentado por los federales mexicanos y por las corrientes progresistas del liberalismo y el republicanismo españoles. Para estos últimos el catolicismo era una propuesta asociada con los ideales del Evangelio y la defensa de la libertad religiosa. Su expresión era la separación de la Iglesia y el Estado y si ésta no era posible, al menos, la garantía de una libertad de conciencia que reclamaron como exigencia de la modernidad cultural y política.

La confrontación entre ambas posiciones fue constante y la historia española y mexicana transitó de una a otra en función de la corriente liberal que estuvo en el poder. El peso dominante del conservadurismo en España hizo del nacional catolicismo un elemento clave en el discurrir del siglo xix. En México, por el contrario, la revolución de Ayutla, la Constitución de 1857 y las Leyes de Reforma, marcaron de forma firme el peso de los valores liberales. La separación de la Iglesia y el Estado fue una realidad incuestionable desde mediados del siglo xix, en contraste con las dificultades que tuvo en España la libertad religiosa. No es de sorprender, pues, que 
los discursos de nación en los dos países mantuvieran una fuerte pugna entre dos concepciones antagónicas. Allí donde el nacional catolicismo fue fuerte en España, se presentó como una presencia débil en México. El anticlericalismo, al mismo tiempo, constituyó un ingrediente central de los discursos identitarios de los liberales mexicanos y de los progresistas - ya republicanos, ya monárquicos - españoles.

\section{REFERENCIAS}

A bós Santabárbara, Ángel Luis, La desamortización de Mendizábal a Madoz, Zaragoza, DELSAN, 2009.

Alonso, Gregorio, La nación en capilla. Ciudadanía católica y cuestión religiosa en España (1793-1874), Granada, Comares, 2014.

Álvarez Junco, José, Mater dolorosa. La idea de España en el siglo XIX, Madrid, Taurus, 2001.

Álvarez Junco, José, “Republicanismo radical y españolismo”, en MoRENO LuZÓn (ed.), 2011, pp. 67-84.

Álvarez Lázaro, Pedro, Masonería y librepensamiento en la España de la Restauración (Aproximación histórica), Madrid, Universidad Pontificia Comillas, 1985.

Álvarez Santalló, Carlos, María Jesús Buxó i Rey y Salvador RoDRÍGUez BECERRA (coords.), La religiosidad popular, Barcelona, Anthropos, Fundación Machado, 1989, 3 volúmenes.

Ameigeiras, Aldo Rubén (comp.), Símbolos, rituales religiosos e identidades nacionales. Los símbolos religiosos y los procesos de construcción política de identidades en Latinoamérica, Buenos Aires, Consejo Latinoamericano de Ciencias Sociales, 2014. 
Archilés, Ferrán, Marta García Carrión e Ismael Saz (eds.), Nación y nacionalización. Una perspectiva europea comparada, Valencia, Publicaciones de la Universidad de Valencia, 2013.

Ávila, Alfredo y Alicia Calderón (coords.), Partidos, facciones y otras calamidades. Debates y propuestas acerca de los partidos políticos en México, siglo XIX, México, Fondo de Cultura Económica, Consejo Nacional para la Cultura y las Artes, Universidad Nacional Autónoma de México, 2012.

Ávila, Alfredo y Virginia Guedea (coords.), La independencia de México. Temas e interpretaciones recientes, México, Universidad Nacional Autónoma de México, 2007.

Barrio Gozalo, Maximiliano, "Reforma y supresión de los regulares en España al final del Antiguo Régimen (1759-1836)”, en Investigaciones Históricas, 20 (2000), pp. 89-118.

Bastian, Jean Pierre, Los disidentes. Sociedades protestantes y revolución en México, 1872-1911, México, Fondo de Cultura Económica, 1989.

Bastian, Jean Pierre, "Leyes de Reforma, ritmos de secularización y modernidad religiosa en México, siglo xix", en Blancarte (coord.), 2013, pp. 141-164.

Bastian, Jean-Pierre (coord.), La modernidad religiosa. Europa latina y América Latina en perspectiva comparada, México, Fondo de Cultura Económica, 2001.

Bautista García, Cecilia Adriana, Las disyuntivas del Estado y de la Iglesia en la consolidación del orden liberal en México, 1866-1910, México, El Colegio de México, Universidad Michoacana de San Nicolás Hidalgo, Fideicomiso Historia de las Américas, 2012.

Blancarte, Roberto (coord.), Las Leyes de Reforma y el Estado laico: importancia histórica y validez contemporánea, México, El Colegio de México, Universidad Nacional Autónoma de México, 2013. 
Boyd, Carolyn P. (ed.), Religión y política en la España contemporánea, Madrid, Centro de Estudios Políticos y Constitucionales, 2007.

BREÑA, Roberto, "Consideraciones sobre el liberalismo mexicano de la primera mitad del siglo XIX”, en BLANCARTE (coord.), 2013, pp. 37-66.

Brubaker, Rogers, "Religion and nationalism: four approaches", en Nations and Nationalism, 18 (1) (2012), pp. 2-20.

Cabrera, Miguel Ángel y Juan Pro (coords.), La creación de las culturas políticas en España, 1808-1833, Madrid, Zaragoza, Marcial Pons Historia, Prensas de la Universidad de Zaragoza, 2014.

Canal, Jordi, "Recaredo contra la revolución: el carlismo y la conmemoración del XIII Centenario de la Unidad Católica (1889)", en Boyd (ed.), 2007, pp. 209-230.

Cannelli, Riccardo, Nación católica y Estado laico. El conflicto político-religioso en México desde la independencia hasta la revolución (1821-1910), México, Instituto Nacional de Estudios Históricos de la Revolución Mexicana, 2012.

CÁrcel Ortí, Vicente, Iglesia y revolución en España (1868-1874). Estudio histórico-jurídico desde la documentación vaticana inédita, Pamplona, EUNSA, 1979.

Casanova, José, Public Religions in the Modern World, Chicago, Chicago University Press, 1994.

Connaughton, Brian, "La nueva historia política y la religiosidad", en Palacios (coord.), 2007.

Connaughton, Brian, Entre la voz de Dios y el llamado de la patria. Religión, identidad y ciudadanía en México. Siglo XIX, México, Universidad Autónoma Metropolitana, El Colegio de México, 2008.

Correa, Eduardo J., El Partido Católico Nacional y sus directores. Explicación de su fracaso y deslinde de responsabilidades, México, Fondo de Cultura Económica, 1991. 
Crane, Daniel Kirk, "La formación de una iglesia nacional mexicana (1854-1867)”, en Religiones y Sociedad, 9 (2000), pp. 105-120.

Cruz, Rafael (ed.), El anticlericalismo, monográfico de la revista Ayer, 27 (1997).

Cueva Merino, Julio de la y Feliciano Montero, "Clericalismo y anticlericalismo entre dos siglos: percepciones recíprocas”, en J. de la CuEva F. Montero, La secularización conflictiva: España (1898-1931), Madrid, Biblioteca Nueva, 2007.

DAvie, Grace, Sociología de la religión, Madrid, Akal, 2011.

Dobbelaere, Karen, "Secularization: A multi-Dimensional Concept", en Current Sociology, 99: 2 (1981).

Espejel López, Laura y Rubén Ruiz Guerra (coords.), El protestantismo en México (1850-1940). La Iglesia metodista episcopal, México, Instituto Nacional de Antropología e Historia, 1991.

Galeana, Patricia, "La revolución cultural de la Reforma”, en Ruiz Guerra (coord.), 2011.

Galeana, Patricia (coord.), Secularización del Estado y la sociedad. 150 aniversario de las Leyes de Reforma, México, Siglo Veintiuno editores, 2010.

García Delgado, José Luis (ed.), España entre dos siglos (1875-1931). Continuidad y cambio, Madrid, Siglo Veintiuno editores, 1991.

García García, Ricardo, Constitucionalismo español y legislación sobre el factor religioso en la primera mitad del siglo XIX (1808-1845), Valencia, Tirant lo Blanc, 2000.

García Ugarte, Marta Eugenia, Poder político y religioso. México siglo XIX, México, Porrúa, 2010, vol. II.

García Ugarte, Marta Eugenia, "Liberalismo y secularización: impacto de la primera reforma liberal", en Galeana (coord.), 2010. 
Gómez Ochoa, Fidel, "Conservadurismo político y catolicismo en España y México, 1830-1860”, en Suárez Cortina, Trejo Estrada y Cano Andaluz (eds.), 2013, pp. 327-364.

González Cuevas, Pedro, Historia de las derechas en España: de la Ilustración a nuestros días, Madrid, Biblioteca Nueva, 2000.

Hale, Charles A., El liberalismo mexicano en tiempos de Mora, 18211853, México, Siglo Veintiuno editores, 1972.

Hale, Charles A., La transformación del liberalismo en México a fines del siglo XIX, México, Fondo de Cultura Económica, 1991.

Hastings, Adrian, La construcción de las nacionalidades. Etnicidad, religión y nacionalismo, Madrid, Akal, 2003.

Haupt, Heinz-Gerard y Dieter Landgew iesche (eds.), Nación y religión en Europa. Sociedades multiconfesionales en los siglos XIX y XX, Zaragoza, Instituto Fernando el Católico, 2010.

Ibarra, Ana Carolina, "La historiografía sobre la Iglesia y el clero", en Ávila y Guedea (coords.), 2007.

Illades, Carlos, "Ciencia y metafísica en el siglo xix", en Illades y LEIDENBERGER (coords.), 2008, pp. 69-114.

Illades, Carlos y Georg Leidenberger (coords.), Polémicas intelectuales del México moderno, México, Consejo Nacional para la Cultura y las Artes, Universidad Autónoma Metropolitana-Cuajimalpa, 2008.

Iparraguirre, Hilda, "Liberalismo, catolicismo y religiosidad popular en la construcción del México moderno", en Iparraguirre y Campos Goenaga (coords.), 2011, pp. 141-164.

Iparraguirre, Hilda y $\mathrm{M}^{\mathrm{a}}$ Isabel Campos Goenaga (coords.), Hacia una nación moderna. La modernidad y la construcción de la nación en México, México, Instituto Nacional de Antropología e Historia, 2011. 
La PARra, Emilio, "Intransigencia y tolerancia religiosa en el primer liberalismo español", en La tolerancia religiosa en la España contemporánea, Mélanges de la Casa de Velásquez, 44-1 (2014), pp. 45-63.

La Parra, Emilio, "Cultura católica: confesionalidad y secularización”, en Cabrera y Pro (coords.), 2014, pp. 127-154.

La Parra, Emilio y Manuel Suárez Cortina (eds.), El anticlericalismo español contemporáneo, Madrid, Biblioteca Nueva, 1997.

López GonzÁlez, Georgina, "La Ley Juárez: reflejo de la cultura jurídica y legal de la primera mitad del siglo XIX", en VázQueZ (coord.), 2010, pp. 191-214.

Louzao, Joseba, "La recomposición religiosa en la modernidad. Un marco conceptual para comprender el enfrentamiento entre laicidad y confesionalidad en la España contemporánea”, en Hispania Sacra, LX: 121 (ene.-jun. 2008), pp. 331-354.

Louzao, Joseba, Soldados de la fe o amantes del progreso. Catolicismo y modernidad en Vizcaya (1890-1923), Palma de Mallorca, Genueve, 2012.

Louzao, Joseba, "Nación y catolicismo en la España contemporánea. Revisitando una interrelación histórica”, en Ayer, 90:2 (2013), pp. 65-89.

Louzao, Joseba (ed.), "Modernidad y catolicismo. Nuevas perspectivas sobre una relación compleja”, en Historia Contemporánea, 51 (2015), http://www.ehu.eus/ojs/index.php/HC/issue/view/1358.

Martí Gilabert, Francisco, La cuestión religiosa en la revolución de 1868-1874, Madrid, Mundial, 1989.

Martínez Albesa, Emilio, La Constitución de 1857. Catolicismo y liberalismo en México, México, Porrúa, 2007, t. II.

Martínez Albesa, Emilio, Catolicismo y liberalismo en México, México, Porrúa, 2007, t. III. 
Martínez Ruiz, Enrique y Margarita Gil, La Iglesia española contra Napoleón. La guerra ideológica, Madrid, ACTAS, 2010.

Matute, Álvaro, Evelia Trejo y Brian Connaugthon (coords.), Estado, Iglesia y sociedad en México. Siglo XIX, México, Grupo Editorial Miguel Ángel Porrúa, 1995.

Menéndez y Pelayo, Marcelino, Historia de los heterodoxos españoles, México, Porrúa, 1983.

Mess, Ludger (ed.), La celebración de la nación. Simbolos, mitos y lugares de memoria, Granada, Comares, 2012.

MinelJ, Sabina, "Faith in nation comes a different guise: modernist versions of religious nationalism", en Nations and Nationalism, 13 (2) (2007), pp. 265-284.

Moliner Prada, Antonio (ed.), La Semana Trágica en Cataluña, Barcelona, Nabla Ediciones, 2009.

Montero, Feliciano, El movimiento católico en España, Madrid, EUDEMA, 1993.

Morales Moya, Antonio, Juan Pablo Fusi y Andrés de Blas (eds.), Historia de la nación y del nacionalismo español, Barcelona, Galaxia Gutemberg, Círculo de Lectores, 2013.

Moreno Luzón, Javier (ed.), Izquierdas y nacionalismos en la España contemporánea, Madrid, Fundación Pablo Iglesias, 2011.

Moreno Luzón, Javier y Ferrán Archiles (eds.), Construir España. Nacionalismo español y procesos de nacionalización, Madrid, Centro de Estudios Políticos y Constitucionales, 2007.

O’Dogherty Madrazo, Laura, De urnas y sotanas. El Partido Católico Nacional en Jalisco, México, Universidad Nacional Autónoma de México, Consejo Nacional para la Cultura y las Artes, 2001. 
O’Dogherty Madrazo, Laura, "El Partido Católico Nacional. Las instituciones liberales al servicio de la restauración católica”, en Ávila y CALDERón (coords.), 2012, pp. 192-236.

Ortiz de Urruela, José Antonio, La Iglesia católica y la revolución de septiembre, Madrid, Lib. de Tejada, 1869.

Palacios, Guillermo (coord.), Ensayos sobre la nueva historia política de América latina. Siglo XIX, México, El Colegio de México, 2007.

Pani, Erika (coord.), Conservadurismo y derechas en la historia de México, México, Fondo de Cultura Económica, Consejo Nacional para la Cultura y las Artes, 2009, 2 volúmenes.

Pérez Ledesma, Manuel, “Estudio preliminar", en La Constitución de 1869, Madrid, Iustel, 2010.

Pérez Memen, Fernando, El episcopado y la Independencia de México (1810-1836) [1972], México, El Colegio de México, 2011.

Pérez Montfort, Ricardo, "Nacionalismo, clero y religión durante la era de Juárez”, en Espejel López y Ruiz Guerra (coords.), 1991, pp. 39-76.

Pérez Vejo, Tomás, "El problema de la nación en las independencias americanas: una propuesta teórica”, en Mexican Studies/Estudios Mexicanos, 24: 2 (2008), pp. 221-244.

Pérez Vejo, Tomás, España en el debate público mexicano, 1836-1867. Aportaciones para una historia de la nación, México, El Colegio de México, Escuela Nacional de Antropología e Historia, Instituto Nacional de Antropología e Historia, 2008.

Perlado, Pedro A., La libertad religiosa en las constituyentes del 69, Pamplona, EUnsA, 1970.

Petschen, Santiago, Iglesia-Estado. Un cambio político. Las constituyentes de 1869, Madrid, Taurus, 1974. 
Puelles Benítez, Manuel de, Educación e ideología en la España contemporánea, Madrid, Tecnos, 1999.

Ramón Solans, Francisco Javier, La Virgen del Pilar dice... Usos políticos y nacionales de un culto mariano en la España contemporánea, Zaragoza, Prensas de la Universidad de Zaragoza, 2014.

Revuelta González, Manuel, La exclaustración, 1833-1840, Madrid, Biblioteca de Autores Cristianos, 1976.

Revuelta González, Manuel, "La recuperación eclesiástica y el rechazo anticlerical en el cambio de siglo", en García Delgado (ed.), 1991, pp. 213-234.

Revuelta González, Manuel, Insurrección o legalidad. Los católicos y la Restauración, Madrid, Consejo Superior de Investigación Científica, 1988.

Robles Muñoz, Cristóbal, "La Cum multa de León XIII y el movimiento católico en España (1882-1884)”, en Hispania Sacra, 39: 79 (1987), pp. 297-348.

Rodríguez O., Jaime E. (coord.), Las nuevas naciones, España y México 1800-1850, Madrid, Mapfre, 2008.

Roselló Soberón, Estela, "Entre el sentido común católico y la opinión pública: el debate mexicano sobre la tolerancia religiosa en 1856", en IlLAdes y LEIDENBERGER (coords.), 2008, pp. 217-260.

RuedA, Germán, La desamortización de Mendizábal y Espartero en España, Madrid, Cátedra, 1986.

Ruiz Guerra, Rubén (coord.), Miradas a la Reforma, México, Universidad Nacional Autónoma de México, 2011.

Salomón Chéliz, Pilar, "El discurso anticlerical en la construcción de una identidad nacional española republicana (1898-1936)", en Hispania Sacra, 54: 110 (2002), pp. 485-498. 
Salomón Chéliz, Pilar, "Construir la identidad nacional desde el anticlericalismo", en Solis y Savarino (coords.), 2011, pp. 99-111.

Santillán, Gustavo, "La secularización de las creencias. Discusiones sobre la tolerancia religiosa en México (1821-1827)”, en Matute, Trejo y Connaugthon (coords.), 1995.

Santillán, Gustavo, “Tolerancia religiosa y moralidad pública, 18211831”, en Signos Históricos, 7 (ene.-jun. 2002), pp. 87-104.

Savarino, Franco y Andrea Mutolo (coords.), El anticlericalismo en México, México, Porrúa, 2008.

Smith, Anthony D., Nacionalismo. Teoría, ideología, historia, Madrid, Alianza, 2004.

Solis, Yves y Franco Savarino (coords.), El anticlericalismo en Europa y América Latina. Una visión trasatlántica, México, Escuela Nacional de Antropología e Historia, Instituto Nacional de Antropología e Historia, Consejo Nacional para la Cultura y las Artes, 2011.

StAPles, Anne, "Secularización, Estado e Iglesia en tiempos de Gómez Farías", en Estudios de Historia Moderna y Contemporánea de México, 10 (1986), pp. 109-123.

SuÁrez Cortina, Manuel, "Entre cirios, barricadas y bayonetas. El anticlericalismo en la España de fin de siglo", en Moliner Prada (ed.), 2009, pp. 25-50.

Suárez Cortina, Manuel, "Federalismo, religión y política en el siglo xix. España y México en perspectiva comparada”, en SuÁrez CorTina, Trejo Estrada y Cano (eds.), 2013, pp. 37-76.

Suárez Cortina, Manuel, Entre cirios y garrotes. Política y religión en la España contemporánea, Santander, Cuenca, Editorial de la Universidad de Cantabria, Universidad de Castilla-La Mancha, 2014. 
SuÁrez Cortina, Manuel, "Élites, ciencia y política en España y México en el fin de siglo", en Trejo Estrada, Cano Andaluz y Suárez Cortina (eds.), 2015, pp. 203-234.

Suárez Cortina, Manuel, Evelia Trejo Estrada y Aurora Cano (eds.), Cuestión religiosa. España y México en la época liberal, México, Universidad Nacional Autónoma de México, 2013.

Tomás y Valiente, Francisco, El marco político de la desamortización en España, Barcelona, Ariel, 1972.

Torre, Renée de la, "Los símbolos y la disputa por la definición de los límites entre fe y política en México", en Ameigeiras (comp.), 2014, pp. 17-38.

Torrubiano Ripoll, Jaime, Política religiosa de la democracia española, Madrid, J. Morata, 1931.

Trejo Estrada, Evelia, Los limites de un discurso. Lorenzo de Zavala, su 'Ensayo histórico' y la cuestión religiosa en México, México, Fondo de Cultura Económica, Universidad Nacional Autónoma de México, 2001.

Trejo Estrada, Evelia, Aurora Cano Andaluz, y Manuel Suárez Cortina (eds.), Élites en México y España. Estudios sobre política y cultura, México, Universidad Nacional Autónoma de México, 2015.

Ullman, Joan Conelly, La Semana Trágica. Estudio sobre las causas socioeconómicas del anticlericalismo en España (1898-1909), Barcelona, Ariel, 1972.

VÁzquez, Josefina Zoraida (coord.), Juárez. Historia y mito, México, El Colegio de México, 2010.

Vega Gómez, Juan, "Ley sobre libertad de cultos”, en Galeana (coord.), 2010, pp. 269 y ss.

Vilar Ramírez, Juan Bautista, Intolerancia y libertad en la España contemporánea. Los orígenes del protestantismo español actual, Madrid, Istmo, 1994. 
ZEPEDA, Beatriz, Enseñar la nación. La educación y la institucionalización de la idea de nación en el México de la Reforma (1855-1876), México, Fondo de Cultura Económica, Consejo Nacional para la Cultura y las Artes, 2012. 